\title{
Narrowing the Range of Environmental Salinities Where Juvenile Meagre (Argyrosomus regius) Can Be Cultured Based on an Osmoregulatory Pilot Study
}

\author{
Ignacio Ruiz-Jarabo ${ }^{1, *+}+\mathbb{C}$, Pura Márquez ${ }^{1,+}$, Luis Vargas-Chacoff ${ }^{2}$, \\ Juan Antonio Martos-Sitcha ${ }^{1} \oplus$, Salvador Cárdenas ${ }^{3}$ and Juan Miguel Mancera ${ }^{1}$ \\ 1 Department of Biology, Faculty of Marine and Environmental Sciences, Instituto Universitario de \\ Investigación Marina (INMAR), Campus de Excelencia Internacional del Mar (CEI-MAR), University of \\ Cadiz, 11510 Puerto Real, Cádiz, Spain; marquez.pura@gmail.com (P.M.); \\ juanantonio.sitcha@uca.es (J.A.M.-S.); juanmiguel.mancera@uca.es (J.M.M.) \\ 2 Facultad de Ciencias, Instituto de Ciencias Marinas y Limnológicas, Universidad Austral de Chile, Casilla \\ 567, Valdivia, Chile; luis.vargas@uach.cl \\ 3 Departamento de Producción, IFAPA Centro El Toruño, Junta de Andalucía, E-11500 El Puerto de Santa \\ María, Cádiz, Spain; salvador.cardenas.rojas@juntadeandalucia.es \\ * Correspondence: ignacio.ruizjarabo@uca.es; Tel.: +34-615-514-755 \\ $\dagger$ These authors contributed equally to this work.
}

Received: 26 September 2018; Accepted: 10 December 2018; Published: 13 December 2018

\begin{abstract}
Aquaculture in Europe aims to diversify and optimize fish farming. The meagre (Argyrosomus regius) arose as a promising species due to its fast growth rates and flesh quality. Thus, it is currently being produced in several Mediterranean countries, mainly in sea-cages and salt-marshes. However, although meagre naturally spend the first years of life in brackish waters, to date it is cultured in seawater. Here, we show that juveniles may not successfully face either freshwater or hyper-osmotic environments as high as $55 \mathrm{ppt}$ salinity. We found that $55 \mathrm{ppt}$ induced catabolism and mobilization of energy metabolites stored in the liver, probably to maintain its osmotic balance. Furthermore, we found that osmoregulatory tissues such as gills managed to maintain plasma osmolality levels without differences in meagre acclimated at 5, 12 and 39 ppt salinity. Our results demonstrate the euryhaline capacity of this species, highlighting that juveniles may be cultured in a wider range of salinities rather than just at seawater. Future studies should focus on optimal environmental salinities for the growth of $A$. regius juveniles, including long-term experiments limited to the range of $5 \mathrm{ppt}$ to full-strength seawater. Minimizing fish energy consumption in osmoregulation could be economically beneficial for the aquaculture industry in Europe.
\end{abstract}

Keywords: aquaculture; Argyrosomus regius; juveniles; meagre; osmoregulation; salinity

\section{Introduction}

Most fish and other aquatic animals inhabit waters with markedly different concentrations of solutes compared to the body fluids [1]. Thus, marine species face continuous dehydration processes due to the high concentration of ions in the seawater, while maintaining their internal environment within a narrow range of ion concentrations [2]. This imbalance with the external medium is achieved through the action of the osmoregulatory tissues, such as the gills, intestine, kidney and skin in teleost fish [3-6]. Marine fish drink seawater, absorb water and ions through their intestinal tract, and the excess of monovalent ions (mostly $\mathrm{Na}^{+}$and $\mathrm{Cl}^{-}$) are secreted actively through the branchial epithelium $[7,8]$. This process occurs in the chloride cells (also called ionocytes or mitochondria-rich 
cells) placed in the gills, and the efflux of ions is pumped by the $\mathrm{Na}^{+} / \mathrm{K}^{+}$-ATPase (NKA) enzyme [9]. This ATP-demanding process is costly and requires constant energy consumption.

Marine fish devote around $10-50 \%$ of the total energy consumption to osmoregulation processes under normal circumstances [10]. Liver, as the major storage tissue of carbohydrates and lipids in teleosts [11], exports energy metabolites such as glucose and triglycerides to the bloodstream to fuel peripheral tissues [12-14]. Liver stores are thus of great importance to face osmoregulatory disturbances [15]. Amino acid consumption is relevant in fish [16], especially after changes in environmental salinity or any other stressful situation [14,17]. Stress responses in teleost fish includes the release of cortisol into the bloodstream [18]. This hormone is involved in the energy management after short- and long-term changes in environmental salinity in teleosts $[19,20]$ including different European aquacultured species like gilthead seabream, Senegalese sole and wedge sole [21-23].

The meagre (Argyrosomus regius) arose as a promising species for aquaculture diversification in several Mediterranean countries [24]. There are many studies focused on different aspects of the culture of this species such as dietary requirements [25-27], stocking density [28], handling procedures [29], and even fillet quality [30]. However, as this is a euryhaline species which naturally spends the first two years of life in estuarine-brackish waters [31,32], and is cultured in salt-marshes with great fluctuations on the environmental salinity throughout the year [33], it should also be relevant to study how environmental salinity affects the osmoregulatory and energy management processes of this species.

The aim of this study was to narrow down the environmental salinities where juvenile meagre can be cultured without negative effects on the osmoregulatory system and, hence, on the energy stores. In an attempt to minimize putative stress imbalances due to inadequate environmental salinities, this study was designed as a pilot study. Thus, the experimental time was reduced to 21 days and a minimum number of fish were used.

\section{Results}

A. regius juveniles did not tolerate freshwater ( $100 \%$ mortality), but at salinities as low as $5 \mathrm{ppt}$, they managed to survive for at least 21 days. Osmoregulatory parameters revealed that the $55 \mathrm{ppt}$ group could not maintain body fluid homeostasis, as evidenced by increased plasma osmolality levels (Figure 1). In contrast, the 5, 12, and 39 ppt juveniles presented similar plasma osmolality levels amongst them. As the water osmolality increased with environmental salinity (within the range from $5-55 \mathrm{ppt})$ fitting in a straight regression line $\left(R^{2}=0.999, p<0.05\right)$, and no variations were found in plasma osmolality in fish acclimated to the range of experimental salinities between 5-39 ppt, we substituted the average plasma osmolality calculated within this range $\left(346 \pm 1 \mathrm{mOsm} \mathrm{kg}^{-1}\right)$ in the regression line calculated for water osmolality, thus resulting in an iso-osmotic salinity for A. regius juveniles of 12 ppt (Figure 1).

Furthermore, branchial NKA activity (Figure 2) was significantly higher in the 55 ppt group as compared to the other groups, while the seawater group was also statistically higher than the iso(12 ppt) and hypo- (5 ppt) osmotic groups, which did not present major differences between them $(p>0.05)$. 


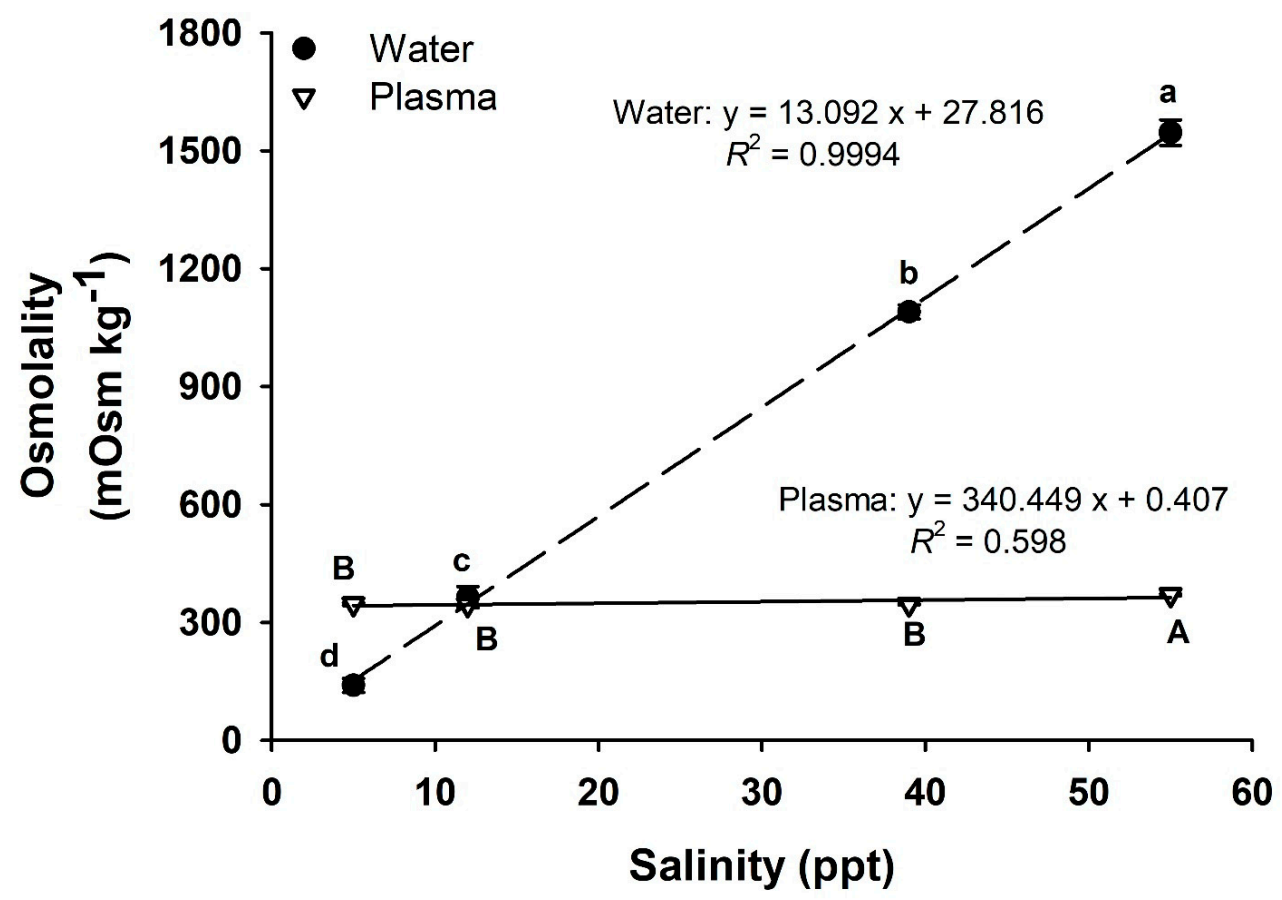

Figure 1. Water and plasma osmolality in Argyrosomus regius juveniles acclimated to different environmental salinities $(5,12,39$, and $55 \mathrm{ppt})$ for 21 days. Results are expressed as the mean \pm standard error of the mean (SEM) $(n=3$ water samples per group; and $n=8-10$ plasma samples per group). Different letters indicate significantly different groups for both water (lowercase letters) and plasma (capital letters) groups ( $p<0.05$, one-way analysis of variance or ANOVA followed by Tukey's post-hoc test).

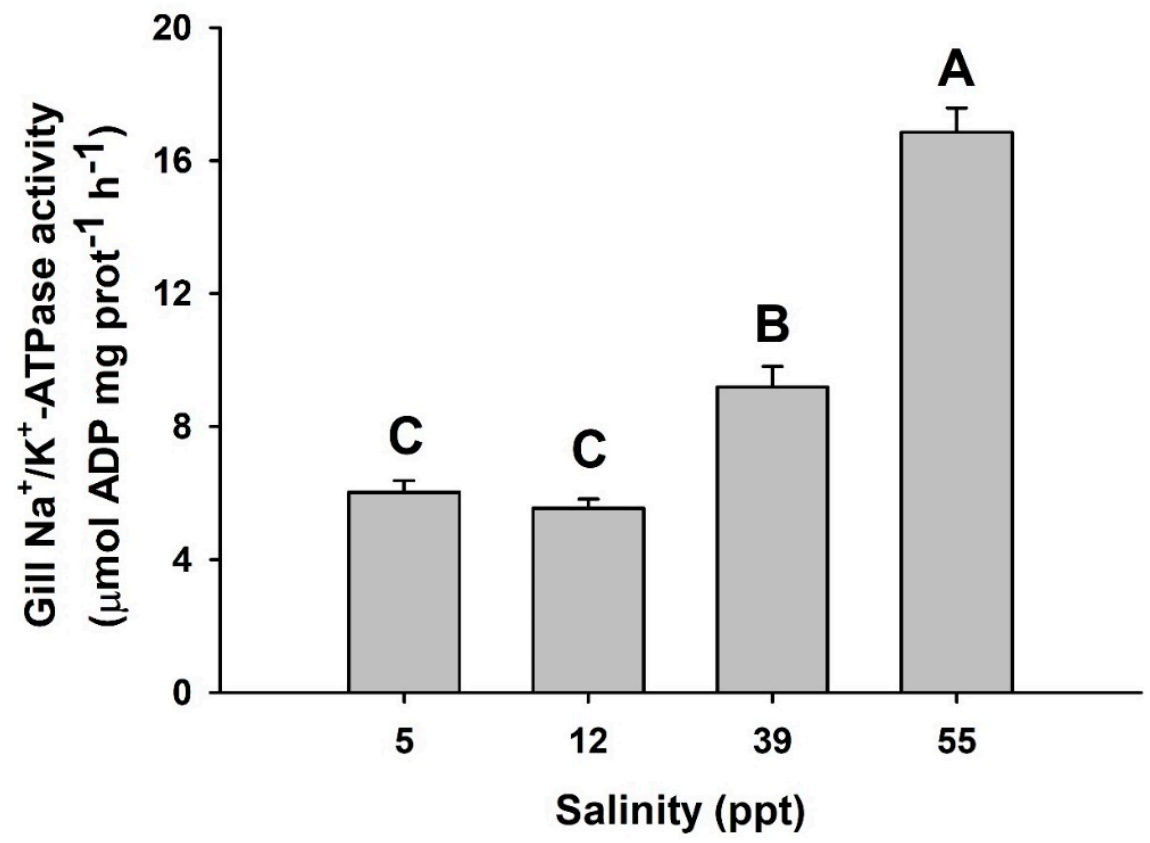

Figure 2. Gill $\mathrm{Na}^{+} / \mathrm{K}^{+}$-ATPase (NKA) activity in $A$. regius juveniles acclimated to different environmental salinities $(5,12,39$, and $55 \mathrm{ppt})$ for 21 days. Results are expressed as the mean \pm SEM $(n=7-10)$. Different letters indicate significantly different groups $(p<0.05$, one-way ANOVA followed by Tukey's post-hoc test). 
The 39 ppt group presented the lowest plasma cortisol values $(p<0.05)$, with significant differences in respect to $12 \mathrm{ppt}$. However, there were no statistical differences in plasma cortisol among the juveniles maintained at 5, 12, and 55 ppt salinity (Figure 3).

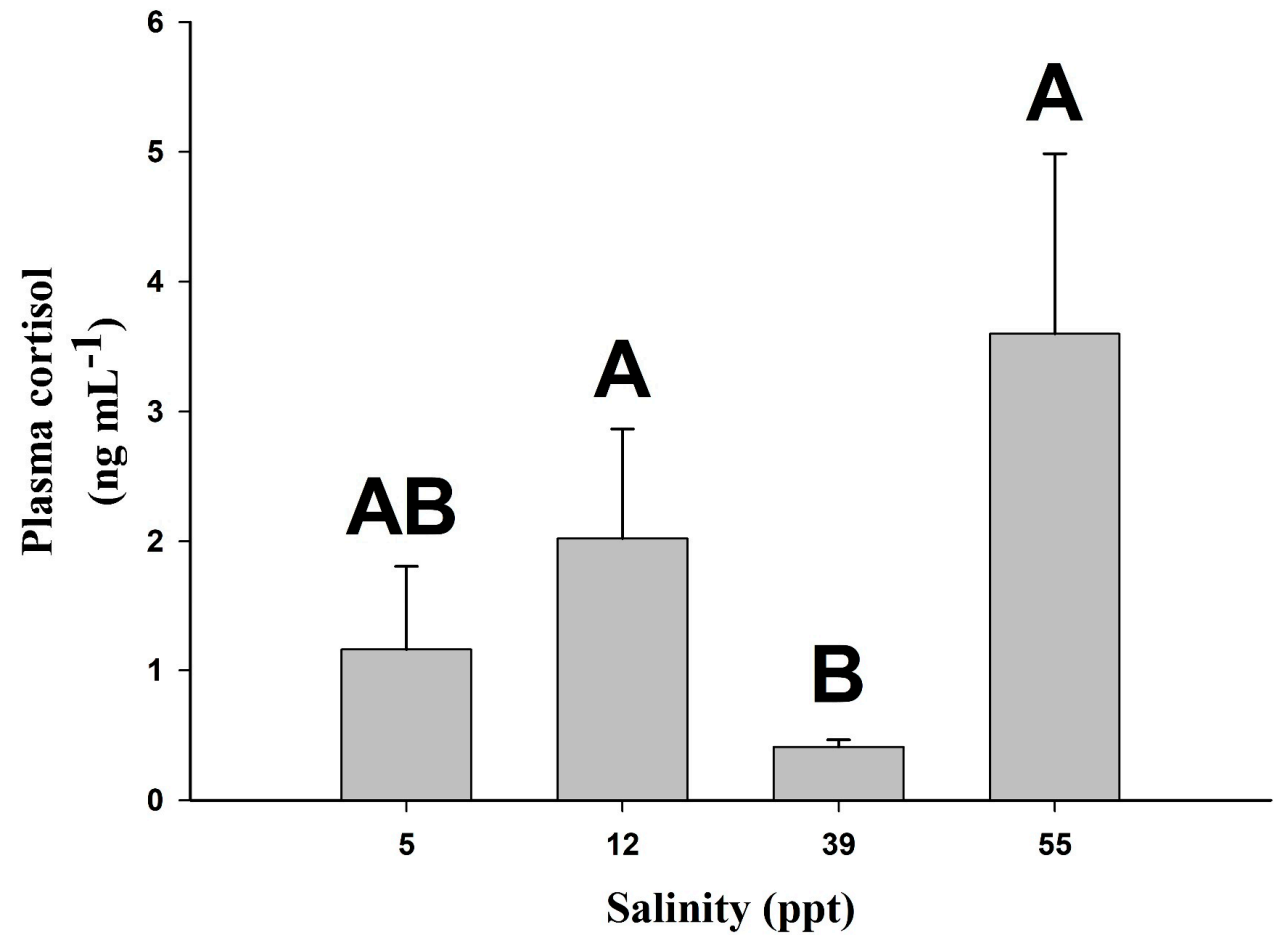

Figure 3. Plasma cortisol concentration in A. regius juveniles acclimated to different environmental salinities $(5,12,39$, and $55 \mathrm{ppt})$ for 21 days. Results are expressed as the mean \pm SEM $(n=7)$. Different letters indicate significantly different groups $(p<0.05$, one-way ANOVA followed by Tukey's post-hoc test).

Table 1 shows the differentiated plasma energy metabolite availabilities in juveniles acclimated to different environmental salinities $(p<0.05)$. Maximum glucose concentration was recorded at $39 \mathrm{ppt}$, minimum concentrations at $5 \mathrm{ppt}$, and intermediate concentrations were found at 12 and $55 \mathrm{ppt}$. Both lactate and protein reached the highest values at $55 \mathrm{ppt}$, being these values statistically different than those observed in the $39 \mathrm{ppt}$ group. Plasma levels of free amino acids increased in the 5 and $12 \mathrm{ppt}$ groups compared to the 39 ppt group. Finally, plasma concentrations of lipid-related metabolites (triglycerides (TAG) and free fatty acids (FFA)) were enhanced at $55 \mathrm{ppt}$, with significant differences between fish at 5 and 55 ppt salinity $(p<0.05)$.

Table 1. Plasma metabolites of A. regius juveniles acclimated to different environmental salinities (5, 12,39 , and $55 \mathrm{ppt}$ ) for 21 days. Data are expressed as the mean \pm standard error of the mean (SEM) $(n=7-10)$.

\begin{tabular}{lcccc}
\hline Variable & $\mathbf{5} \mathbf{p p t}$ & $\mathbf{1 2} \mathbf{p p t}$ & $\mathbf{3 9} \mathbf{~ p p t}$ & $\mathbf{5 5} \mathbf{p p t}$ \\
\hline Glucose $\mathbf{( m M )}$ & $2.8 \pm 0.1 \mathrm{c}$ & $3.6 \pm 0.2 \mathrm{bc}$ & $5.1 \pm 0.4 \mathrm{a}$ & $3.8 \pm 0.2 \mathrm{~b}$ \\
Lactate $(\mathbf{m M})$ & $1.4 \pm 0.2 \mathrm{ab}$ & $1.5 \pm 0.1 \mathrm{a}$ & $0.9 \pm 0.1 \mathrm{~b}$ & $1.5 \pm 0.2 \mathrm{a}$ \\
Proteins $\left(\mathbf{g ~ d L} \mathbf{~ L}^{-\mathbf{1}}\right)$ & $30.1 \pm 1.2 \mathrm{~b}$ & $31.5 \pm 0.6 \mathrm{ab}$ & $30.4 \pm 0.8 \mathrm{~b}$ & $33.5 \pm 0.7 \mathrm{a}$ \\
Amino acid $(\mathbf{m M})$ & $16.0 \pm 0.8 \mathrm{a}$ & $15.7 \pm 0.4 \mathrm{a}$ & $13.1 \pm 0.5 \mathrm{~b}$ & $13.9 \pm 0.5 \mathrm{ab}$ \\
TAG $(\mathbf{m M})$ & $0.9 \pm 0.1 \mathrm{~b}$ & $1.1 \pm 0.1 \mathrm{ab}$ & $1.0 \pm 0.1 \mathrm{ab}$ & $1.4 \pm 0.1 \mathrm{a}$ \\
FFA (mM) & $1.7 \pm 0.2 \mathrm{~b}$ & $2.6 \pm 0.2 \mathrm{~b}$ & $2.6 \pm 0.2 \mathrm{~b}$ & $5.4 \pm 0.4 \mathrm{a}$ \\
\hline
\end{tabular}

Different letters indicate significantly different groups $(p<0.05$, one-way ANOVA followed by Tukey's post-hoc test). TAG means triglycerides, and FFA, free fatty acids. 
The hepatic parameters of juvenile A. regius are shown in Table 2. The hepatosomatic index (HSI) values of the $55 \mathrm{ppt}$ group were significantly lower than those of the $39 \mathrm{ppt}$ group $(p<0.05)$. Glycogen stores as well as amino acids decreased while free glucose levels increased significantly in the 55 ppt group compared to the other groups $(p<0.05)$. No major changes in hepatic TAG or FFA were observed for the distinct groups assessed.

Table 2. Hepatic parameters (the hepatosomatic index (HSI) and metabolites) of A. regius juveniles acclimated to different environmental salinities $(5,12,39$, and $55 \mathrm{ppt})$ for 21 days. Data are expressed as the mean \pm SEM $(n=7-10)$ and refer to the liver as an individual unit of storage.

\begin{tabular}{|c|c|c|c|c|}
\hline Variable & 5 ppt & $12 \mathrm{ppt}$ & $39 \mathrm{ppt}$ & $55 \mathrm{ppt}$ \\
\hline HSI (\%) & $2.0 \pm 0.2 \mathrm{ab}$ & $1.8 \pm 0.2 \mathrm{ab}$ & $2.2 \pm 0.2 \mathrm{a}$ & $1.5 \pm 0.1 \mathrm{~b}$ \\
\hline Glycogen (mg liver ${ }^{-1}$ ) & $36.8 \pm 2.2 \mathrm{ab}$ & $34.1 \pm 2.2 \mathrm{~b}$ & $36.6 \pm 2.8 \mathrm{a}$ & $26.6 \pm 4.0 \mathrm{c}$ \\
\hline Glucose (mg liver ${ }^{-1}$ ) & $5.1 \pm 0.3 \mathrm{ab}$ & $4.6 \pm 0.3 \mathrm{~b}$ & $4.3 \pm 0.4 b$ & $6.1 \pm 0.6 \mathrm{a}$ \\
\hline TAG (mg liver ${ }^{-1}$ ) & $4.5 \pm 0.3$ & $3.7 \pm 0.2$ & $4.9 \pm 0.5$ & $4.3 \pm 0.2$ \\
\hline Amino acid ( $\mu$ mol liver $\left.{ }^{-1}\right)$ & $258 \pm 16$ a & $267 \pm 9 \mathrm{a}$ & $289 \pm 18$ a & $172 \pm 14 b$ \\
\hline
\end{tabular}

Different letters indicate significantly different groups $(p<0.05$, one-way ANOVA followed by Tukey's post-hoc test). TAG means triglycerides.

Changes in weight gain (WG) and condition factor (K) for juveniles acclimated to 5, 15, 39, and 55 ppt salinity over the experimental period (21 days) are shown in Table 3 . In all cases, the 55 ppt group showed statistically lower values compared to the other groups $(p<0.05)$.

Table 3. Changes in weight gain (WG) and condition factor (K) values in A. regius juveniles acclimated to different environmental salinities $(5,12,39$, and $55 \mathrm{ppt})$ for 21 days. Data are expressed as the mean \pm SEM $(n=10)$. Different letters indicate significant differences among groups $(p<0.05$, one-way ANOVA followed by Tukey's post-hoc test).

\begin{tabular}{lcccc}
\hline Variable & $\mathbf{5} \mathbf{p p t}$ & $\mathbf{1 2} \mathbf{p p t}$ & $\mathbf{3 9} \mathbf{p p t}$ & $\mathbf{5 5} \mathbf{p p t}$ \\
\hline WG (\%) & $25.4 \pm 10.7 \mathrm{a}$ & $16.9 \pm 6.4 \mathrm{a}$ & $20.0 \pm 9.9 \mathrm{a}$ & $-12.6 \pm 7.0 \mathrm{~b}$ \\
K (no units) & $0.99 \pm 0.01 \mathrm{a}$ & $0.96 \pm 0.01 \mathrm{a}$ & $0.99 \pm 0.01 \mathrm{a}$ & $0.89 \pm 0.01 \mathrm{~b}$ \\
\hline
\end{tabular}

\section{Discussion}

The present study is the first to test and propose a range of appropriate environmental salinities for culture of $A$. regius juveniles. Based on osmoregulatory responses and energy management, future approaches should be limited to the range from $5 \mathrm{ppt}$ salinity to full-strength seawater, as freshwater and hyper-osmotic environments above seawater have detrimental consequences on this life stage. Aquaculture of this species may be relevantly optimized by modifying environmental salinity. For this purpose, long-term experiments should be conducted to better characterize the best environmental salinity for the culture of $A$. regius juveniles and other life stages.

The results of this study show that $A$. regius juveniles managed to maintain their plasma osmolality levels constant within the range from 5-39 ppt salinity. This euryhaline response coincides with what was described in the sciaenid shi drum, Umbrina cirrosa [34], the European seabass, Dicentrarchus labrax [35] and the sub-Antarctic Eleginops maclovinus [36]. However, other euryhaline species cultured in Europe such as Sparus aurata, Dicologoglossa cuneata and Scophthalmus maximus manage to maintain constant plasma osmolality levels within a narrower range of salinities, from brackish water close to the iso-osmotic point of these species to seawater $[23,37,38]$, while Solea senegalensis, Scophthalmus rhombus and Pagrus pagrus show increasing plasma osmolality as environmental salinity increased [39-41].

Plasma osmolality levels are controlled by the osmoregulatory tissues, with branchial NKA activity as an enzyme of paramount relevance [1,9]. This enzyme is placed in the basolateral membrane of specialized branchial cells called chloride-cells, or mitochondrial-rich cells, or ionocytes. These cells actively secrete ions (mainly $\mathrm{Na}^{+}$and $\mathrm{Cl}^{-}$) through the branchial epithelium energized mainly by 
NKA in hyperosmotic environments, while actively absorb these ions in hypo-osmotic environments in collaboration with other basal/apical ion transporters/channels [41]. In this sense, extreme salinities induce two different NKA profiles depending on the species. Our results evidenced higher branchial NKA activity at higher salinities, as was described for S. senegalensis and S. rhombus [40,41]. The other NKA activity profile in fish was described in S. aurata, Mugil liza and D. labrax, showing the lowest branchial NKA activity in salinities close to the iso-osmotic point of these species and increased activities in the extreme salinities [35,37,42]. However, it was described for the sciaenid $U$. cirrosa that juveniles maintained for 84 days within a range of environmental salinities from 4 to $40 \mathrm{ppt}$, did not show differences in their branchial NKA activity [34]. Changes in the NKA activity in gills are related to the quantity and quality of the NKA subunits in the branchial ionocytes [43,44]. Moreover, several ionocyte populations were described depending on the environmental salinity, with differentiated ion-transport processes aiming at a sharp control of ion fluxes between the blood and the external media $[45,46]$. All these osmoregulatory changes are under endocrine control, with cortisol as a hormone involved in both hypo- and hyperosmotic acclimation [47].

In this study, plasma cortisol levels were maximum at the highest environmental salinity ( $55 \mathrm{ppt})$. Under such an extreme condition, the described high plasma cortisol concentrations in A. regius juveniles may be related to the high NKA activity in the gills. Altogether with the mineralocorticoid functioning of cortisol, that allow teleost fish to modify the osmoregulatory processes and acclimate to different environmental salinities [48], this hormone is also related to chronic stress responses [18]. In this sense, cortisol stimulates several aspects of intermediary metabolism and sustained high levels are interpreted as a signal of distress [49], regulating lipid metabolism and possibly promoting gluconeogenesis [50]. In this line, it was described that chronic stress situations, such as inadequate stocking densities, induced consumption of hepatic stores, increased glycolytic and glycogenolytic pathways, mobilized lipids and increased amino acid consumption in S. rhombus, D. cuneata, Rhamdia quelen, P. pagrus and E. maclovinus [51-55]. These cortisol actions are also reflected in the groups maintained at 5 ppt, but especially in those maintained at 12 ppt salinity. In these groups, plasma cortisol concentration was higher (but not significantly higher) than at $39 \mathrm{ppt}$ (but lower than at $55 \mathrm{ppt})$, coinciding with lowered HSI and stored liver glycogen. Thus, other groups rather than the seawater-acclimated (39 ppt) group are exposed to long-term energy-consuming conditions. Thus, growing at salinities different than $39 \mathrm{ppt}$ can result in a slight decrease in growth if maintained.

Energy mobilization, as seen by the differentiated plasma free fatty acids, TAG and free protein levels in the $55 \mathrm{ppt}$ salinity group, are in accordance with the previous idea of cortisol acting as an anabolic hormone. Moreover, $A$. regius acclimated to $55 \mathrm{ppt}$ salinity for 21 days showed the lowest glycogen levels and HSI of all groups tested. Glucose is thus mobilized from liver to the plasma at higher salinities, while amino acids and lipids may be consumed from other tissues. According to our results, the idea of energy demand for osmoregulation being minimized in water salinity close to the iso-osmotic condition in fish $[10,42,56]$ should be better studied in the future for $A$. regius juveniles.

The present study, although designed as a pilot study without replicated tanks, show that A. regius juveniles maintained at $55 \mathrm{ppt}$ salinity for 21 days decreased their body weights and condition factor. These results are supported by the low glycogen stores in the liver at this salinity, as well as the high concentrations of plasma proteins and lipids, mobilized to fuel energy demanding tissues. Thus, A. regius growth seems to be compromised at hyper-osmotic environments such as 55 ppt salinity, while failing to survive in freshwater. Scarce literature has evaluated growth rates of sciaenids cultured at different environmental salinities. It was published that $U$. cirrosa and Argyrosomus japonicus juveniles showed better growth rates at full-strength seawater (SW), equal or lower growth at iso-osmotic salinities (10-12 ppt), and displayed the lowest performances at hypo-osmotic environments ( $4-5$ ppt salinity) $[34,57]$. Moreover, it has been demonstrated that $A$. regius juveniles acclimated to environmental salinities close to the iso-osmotic point for this species (12 ppt) enhanced igf1 mRNA expression, thus suggesting better growth rates [58]. Altogether, this study 
highlights the differentiated responses in the osmoregulatory processes between closely-related fish species, which may have important consequences on their growth at different environmental salinities.

\section{Materials and Methods}

\subsection{Experimental Design}

Juvenile A. regius were provided by the El Toruño Center for Investigation and Formation in Fishery and Aquaculture (IFAPA, El Puerto de Santa María, Cádiz, Spain) in April 2009. All experimental procedures complied with the guidelines of the University of Cadiz (Spain) and the European Union (86/609/EU) for the use of animals in research, and the Commission of Ethics and Animal Research of the University of Cadiz approved the experiment.

One-year-old seawater-acclimated A. regius juveniles (144.67 $\pm 5.50 \mathrm{~g}$ body weight, mean \pm standard error of the mean, SEM) were transferred to the wet laboratories of the Faculty of Marine and Environmental Sciences (University of Cadiz, Puerto Real, Cádiz, Spain), where they were acclimated to seawater (39 ppt) in circular 1000-L tanks until the start of the experiment. Preliminary experiments indicated that after an abrupt change and five-days acclimation period from 39 to $12 \mathrm{ppt}$, the minimum salinity at which $A$. regius juveniles could be held with no mortality was 5 ppt. Fish could not tolerate 0 ppt (100\% mortality within a few hours) and thus 5 ppt was the lowest salinity investigated in this study.

After 60 days of acclimation, the juveniles $(n=40)$ were anaesthetized with 2-phenoxyethanol (Sigma, St. Louis, MO, USA; P1126, $0.5 \mathrm{~mL} \mathrm{~L}^{-1}, 0.05 \% v / v$ ), had total length and body weight measured, and were randomly divided into four $400-\mathrm{L}$ tanks ( $n=10$ juveniles per tank). Three tanks contained SW (39 ppt, $1090 \mathrm{mOsm} \mathrm{kg}^{-1} \mathrm{H}_{2} \mathrm{O}$ ), and one was kept at a salinity of $12 \mathrm{ppt}$ (364 mOsm $\mathrm{kg}^{-1} \mathrm{H}_{2} \mathrm{O}$, presumably close to the iso-osmotic point of this species). After five days, the juveniles from the 39 ppt tanks were transferred to similar tanks with salinities of either $12 \mathrm{ppt}$ (364 mOsm $\mathrm{kg}^{-1} \mathrm{H}_{2} \mathrm{O}$; one tank), 39 ppt (1090 mOsm kg ${ }^{-1} \mathrm{H}_{2} \mathrm{O}$; one tank, control), or 55 ppt (1546 mOsm kg ${ }^{-1}$ $\mathrm{H}_{2} \mathrm{O}$; one tank). The group challenged to $55 \mathrm{ppt}$ salinity was included as in the South of Spain, fish are cultured in saltmarshes that could be extremely hypersaline in summer months. Previous studies conducted in the same geographical area, with locally-important species such as gilthead seabream (Sparus aurata), Senegalese sole (Solea senegalensis) and wedge sole (Dicologoglossa cuneata), included an experimental group challenged to $55 \mathrm{ppt}$ salinity, establishing a common ground to compare the results obtained in this study [21,23,59]. In turn, the juveniles first acclimated in the $12 \mathrm{ppt}$ tank were transferred to a tank with a salinity of $5 \mathrm{ppt}\left(140 \mathrm{mOsm} \mathrm{kg}{ }^{-1} \mathrm{H}_{2} \mathrm{O}\right)$. The experimental salinities were assessed in single tanks as this study was designed as a pilot experiment aiming at reducing the number of animals employed. We refused to include more tanks with less fish in each (and therefore augment the statistical independence of the data) as recent studies has shown this species is less stressed in high stocking densities [28] due to its gregarious natural behavior [60]. Each tank had its own water recirculation system equipped with an external filter (Hydor Prime 30; Hydor, Sacramento, CA, USA) to ensure optimal water conditions. Every other day, approximately $20 \%$ of the water in each tank was replaced. The experimental salinities were obtained by mixing SW with dechlorinated tap water or by mixing SW with natural marine salt (Salina de La Tapa, Puerto de Santa María, Cádiz, Spain). Juveniles were maintained for 21 days under natural photoperiod (July; latitude $36^{\circ} 31^{\prime} 34^{\prime \prime} \mathrm{N}$ ) and water temperature $\left(21-22{ }^{\circ} \mathrm{C}\right)$ conditions. Temperature, salinity, oxygen and ammonia were monitored daily inside the tanks, and no major changes were observed during the experimental period (temperature, $18.7-19.3{ }^{\circ} \mathrm{C}$; oxygen, $>5 \mathrm{mg} \mathrm{O}_{2} \mathrm{~L}^{-1}$; and ammonia, 0.0-0.2 $\mathrm{mg} \mathrm{NH}_{4} \mathrm{~L}^{-1}$ ). Juveniles were fed commercial dry pellets once daily in proportion to $1 \%$ body weight (Dibaq Diproteg SA, Segovia, Spain). No mortalities were recorded during the experiment. 


\subsection{Blood and Tissue Sampling}

Blood and tissue samples were taken at day 21 post-transfer. Animals were fasted for $24 \mathrm{~h}$ before sampling. Juveniles were deeply anaesthetized with 2-phenoxyethanol $\left(1 \mathrm{~mL} \mathrm{~L}^{-1}, 0.1 \% v / v\right)$, and were then weighed and sampled. Blood was collected from the caudal peduncle into previously cooled $1 \mathrm{~mL}$ ammonia-heparinized syringes. Euthanization was confirmed by severing the spinal cord with a sharp knife. Plasma for each fish was separated from whole blood by centrifugation ( $3 \mathrm{~min}$, $4{ }^{\circ} \mathrm{C}$ at $10,000 \times g$ ), immediately frozen in liquid nitrogen, and stored at $-80{ }^{\circ} \mathrm{C}$ until analysis. From each fish, the second gill arch on the left side was excised, dried with absorbent paper, and a small portion was cut using fine-point scissors. These small portions were placed in $100 \mu \mathrm{L}$ of ice-cold sucrose-EDTA-imidazole buffer (150 mM sucrose, $10 \mathrm{mM}$ EDTA, and $50 \mathrm{mM}$ imidazole, $\mathrm{pH}$ 7.3) and frozen at $-80^{\circ} \mathrm{C}$ until analyses of NKA activity. The liver was excised, weighed, and snap frozen at $-80^{\circ} \mathrm{C}$.

\subsection{Plasma Measurements}

Plasma and water osmolality were measured with a Fiske One-Ten vapor pressure osmometer (Fiske Associates, Advanced Instruments, Norwood, MA, USA). The isosmotic point was estimated according to previous studies [61] as the intersect of the iso-osmotic line and the regression lines between plasma and water osmolality. Plasma glucose, lactate, and TAG levels were measured on 96-well microplates using commercial kits (Spinreact, St. Esteve de Bas, Spain; Glucose-HK Ref. 1001200; Lactate Ref. 1001330; TAG Ref. 100131101). Total plasma proteins were determined using the Bicinchoninic Acid Protein Assay Kit \#23225 (Pierce, Rockford, IL, USA) with bovine serum albumin as the standard. Total $\alpha$-amino acid levels were assessed through colorimetric analysis using the ninhydrin method [62] adapted to microplates and using L-alanine as the standard. Free fatty acids were analyzed with a commercial kit (Wako Chemicals $\mathrm{GmbH}$, (Neuss, Germany) using oleic acid as the standard. All assays were carried out on a microplate reader (Bio-Tek Instruments, Winooski, VT, USA) using the KCjunior Gen5 Data Analysis Software for Microsoft Windows XP. Plasma cortisol levels were measured using an enzyme-linked immunosorbent assay performed in microtiter plates (MaxiSorp, Nunc, Roskilde, Denmark), as previously described for other teleost species [63].

\subsection{Gill $\mathrm{Na}^{+} / \mathrm{K}^{+}$-ATPase Activity}

Gill NKA activity was determined as previously described [64], with modifications [65].

\subsection{Liver Metabolite Levels}

Each excised and frozen liver was homogenized as described previously [66]. The homogenate was centrifuged ( $30 \mathrm{~min}, 13,000 \times g, 4{ }^{\circ} \mathrm{C}$ ), and the supernatants were stored in different aliquots at $-80^{\circ} \mathrm{C}$ until use in the metabolite assays. Tissue glycogen concentrations were assessed using described methodologies [67]. The levels of glucose after glycogen breakdown (i.e., after subtracting free glucose levels) were determined with a commercial kit (Spinreact, St. Esteve de Bas, Spain). Total $\alpha$-amino acid and TAG levels were determined as described above for the plasma samples.

\subsection{Growth Parameters}

The evaluated parameters were weight gain (WG) and Fulton's condition factor (K). At the end of the experimental period (day 21), the hepatosomatic index (HSI) was also calculated. The above parameters were determined as follows:

$$
\begin{aligned}
\text { WG }(\%) & =100 \times\left((\mathrm{Wf}-\mathrm{Wi}) * \mathrm{Wi}^{-1}\right) \\
\mathrm{K} & =100 \times\left(\mathrm{Wt} \mathrm{Lt}^{-3}\right) \\
\mathrm{HSI} & =100 \times\left(\mathrm{Wl} \mathrm{Wt}^{-1}\right)
\end{aligned}
$$


where $\mathrm{Wt}=$ total wet body weight (g); $\mathrm{Wf}=$ final wet body weight $(\mathrm{g}) ; \mathrm{Wi}=$ initial wet body weight $(\mathrm{g}) ; \mathrm{Wl}=$ wet liver weight $(\mathrm{g})$; and $\mathrm{Lt}=$ total body length $(\mathrm{cm})$.

\subsection{Statistics}

Differences between groups were tested using a one-way analysis of variance (ANOVA) with environmental salinity as the factor of variance. When necessary, data were logarithmically transformed to fulfil the requirements for parametric ANOVA. Normality and homogeneity of variances were analyzed using the Kolmogorov-Smirnov's and the Levene's test, respectively. When ANOVA yielded significant differences, Tukey's post-hoc test was used to identify significantly different groups. Statistical significance was accepted at $p<0.05$. All the results are given as mean \pm SEM.

\section{Conclusions}

The present study, designed as a pilot study, indicates that $A$. regius could be considered as a partially euryhaline species. In this sense, freshwater resulted too much of a challenge, while a hyper-osmotic environment of $55 \mathrm{ppt}$ salinity induced consumption of energy stores and fish failed to osmoregulate properly. However, culture of this species within a range covering $5 \mathrm{ppt}$ to seawater salinity may be further evaluated. Growth rates in the appropriate salinity can be favored, with the consequent economic benefits for the Aquaculture sector in Europe.

Author Contributions: S.C. and J.M.M. designed the experiment. I.R.-J., P.M., L.V.-C. and J.A.M.-S. conducted the experiments and analysis. I.R.-J., L.V.-C. and J.A.M.-S. interpreted the results. I.R.-J. and J.M.M. wrote the draft of the manuscript. All authors critically revised the manuscript.

Funding: This study was partly supported by grant AGL2016-76069-C2-1-R (Ministerio de Economía y Competitividad, Spain) awarded to J.M.Mancera. I. Ruiz-Jarabo, J.A. Martos-Sitcha and J.M. Mancera belong to the Fish Welfare and Stress Network (AGL2016-81808-REDT), supported by the Agencia Estatal de Investigación (MINECO, Spanish Government).

Acknowledgments: The authors wish to thank the El Toruño IFAPA Center (El Puerto de Santa María, Cádiz, Spain) for providing experimental fish.

Conflicts of Interest: The authors declare no competing or financial interests. The funding sponsors had no role in the design of the study, in the collection, analyses, or interpretation of data; in the writing of the manuscript, and in the decision to publish the results.

\section{References}

1. McCormick, S.D.; Farrell, A.P.; Brauner, C.J. Euryhaline Fishes; Academic Press: Oxford, UK, 2013; Volume 32.

2. Evans, D.H. Teleost fish osmoregulation: What have we learned since August Krogh, Homer Smith, and Ancel Keys. Am. J. Physiol. 2008, 295, R704-R713. [CrossRef] [PubMed]

3. Arjona, F.J.; Vargas-Chacoff, L.; Ruiz-Jarabo, I.; Gonçalves, O.; Pâscoa, I.; Martín del Río, M.P.; Mancera, J.M. Tertiary stress responses in Senegalese sole (Solea senegalensis Kaup, 1858) to osmotic challenge: Implications for osmoregulation, energy metabolism and growth. Aquaculture 2009, 287, 419-426. [CrossRef]

4. Ruiz-Jarabo, I.; Gregorio, S.F.; Gaetano, P.; Trischitta, F.; Fuentes, J. High rates of intestinal bicarbonate secretion in seawater tilapia (Oreochromis mossambicus). Comp. Biochem. Physiol. A 2017, 207, 57-64. [CrossRef] [PubMed]

5. Ruiz-Jarabo, I.; González-Wevar, C.A.; Oyarzún, R.; Fuentes, J.; Poulin, E.; Bertrán, C.; Vargas-Chacoff, L. Isolation driven divergence in osmoregulation in Galaxias maculatus (Jenyns, 1848) (Actinopterygii: Osmeriformes). PLoS ONE 2016, 11, e0154766. [CrossRef] [PubMed]

6. Hiroi, J.; Kaneko, T.; Seikai, T.; Tanaka, M. Developmental sequence of chloride cells in the body skin and gills of Japanese flounder (Paralichthys olivaceus) larvae. Zool. Sci. 1998, 15, 455-460. [PubMed]

7. Carvalho, E.S.; Gregorio, S.F.; Power, D.M.; Canario, A.V.; Fuentes, J. Water absorption and bicarbonate secretion in the intestine of the sea bream are regulated by transmembrane and soluble adenylyl cyclase stimulation. J. Comp. Physiol. B 2012, 182, 1069-1080. [CrossRef] [PubMed] 
8. Bystriansky, J.S.; Schulte, P.M. Changes in gill $\mathrm{H}^{+}$-ATPase and $\mathrm{Na}^{+} / \mathrm{K}^{+}$-ATPase expression and activity during freshwater acclimation of Atlantic salmon (Salmo salar). J. Exp. Biol. 2011, 214, 2435-2442. [CrossRef]

9. McCormick, S.D.; Regish, A.M.; Christensen, A.K. Distinct freshwater and seawater isoforms of $\mathrm{Na}^{+} / \mathrm{K}^{+}$-ATPase in gill chloride cells of Atlantic salmon. J. Exp. Biol. 2009, 212, 3994-4001. [CrossRef]

10. Boeuf, G.; Payan, P. How should salinity influence fish growth? Comp. Biochem. Physiol. C 2001, 130, 411-423.

11. Chen, Q.L.; Luo, Z.; Pan, Y.X.; Zheng, J.L.; Zhu, Q.L.; Sun, L.D.; Zhuo, M.Q.; Hu, W. Differential induction of enzymes and genes involved in lipid metabolism in liver and visceral adipose tissue of juvenile yellow catfish Pelteobagrus fulvidraco exposed to copper. Aquat. Toxicol. 2013, 136, 72-78. [CrossRef]

12. Polakof, S.; Panserat, S.; Soengas, J.L.; Moon, T.W. Glucose metabolism in fish: A review. J. Comp. Physiol. B 2012, 182, 1015-1045. [CrossRef] [PubMed]

13. Toni, C.; Martos-Sitcha, J.A.; Ruiz-Jarabo, I.; Mancera, J.M.; Martinez-Rodriguez, G.; Pinheiro, C.G.; Heinzmann, B.M.; Baldisserotto, B. Stress response in silver catfish (Rhamdia quelen) exposed to the essential oil of Hesperozygis Ringens. Fish Physiol. Biochem. 2015, 41, 129-138. [CrossRef] [PubMed]

14. Costas, B.; Conceicao, L.; Aragao, C.; Martos, J.A.; Ruiz-Jarabo, I.; Mancera, J.; Afonso, A. Physiological responses of Senegalese sole (Solea senegalensis Kaup, 1858) after stress challenge: Effects on non-specific immune parameters, plasma free amino acids and energy metabolism. Aquaculture 2011, 316, 68-76. [CrossRef]

15. Martos-Sitcha, J.A.; Mancera, J.M.; Calduch-Giner, J.A.; Yufera, M.; Martinez-Rodriguez, G.; Perez-Sanchez, J. Unraveling the tissue-specific gene signatures of gilthead sea bream (Sparus aurata L.) after hyper- and hypo-osmotic challenges. PLoS ONE 2016, 11, e0148113. [CrossRef] [PubMed]

16. Costas, B.; Aragao, C.; Ruiz-Jarabo, I.; Vargas-Chacoff, L.; Arjona, F.; Mancera, J.M.; Dinis, M.T.; Conceicao, L. Different environmental temperatures affect amino acid metabolism in the eurytherm teleost Senegalese sole (Solea senegalensis Kaup, 1858) as indicated by changes in plasma metabolites. Amino Acids 2012, 43, 327-335. [CrossRef]

17. Aragao, C.; Costas, B.; Vargas-Chacoff, L.; Ruiz-Jarabo, I.; Dinis, M.T.; Mancera, J.M.; Conceicao, L.E. Changes in plasma amino acid levels in a euryhaline fish exposed to different environmental salinities. Amino Acids 2010, 38, 311-317. [CrossRef]

18. Wunderink, Y.S.; Engels, S.; Halm, S.; Yufera, M.; Martinez-Rodriguez, G.; Flik, G.; Klaren, P.H.M.; Mancera, J.M. Chronic and acute stress responses in Senegalese sole (Solea senegalensis): The involvement of cortisol, CRH and CRH-BP. Gen. Comp. Endocrinol. 2011, 171, 203-210. [CrossRef]

19. Mommsen, T.P.; Vijayan, M.M.; Moon, T.W. Cortisol in teleosts: Dynamics, mechanisms of action, and metabolic regulation. Rev. Fish Biol. Fish. 1999, 9, 211-268. [CrossRef]

20. Barton, B.A. Stress in fishes: A diversity of responses with particular reference to changes in circulating corticosteroids. Integr. Comp. Biol. 2002, 42, 517-525. [CrossRef]

21. Arjona, F.J.; Vargas-Chacoff, L.; Ruiz-Jarabo, I.; Martin del Rio, M.P.; Mancera, J.M. Osmoregulatory response of Senegalese sole (Solea senegalensis) to changes in environmental salinity. Comp. Biochem. Physiol. A 2007, 148, 413-421. [CrossRef]

22. Laiz-Carrion, R.; Guerreiro, P.M.; Fuentes, J.; Canario, A.V.M.; Martin Del Rio, M.P.; Mancera, J.M. Branchial osmoregulatory response to salinity in the gilthead sea bream, Sparus Auratus. J. Exp. Zool. A 2005, 303A, 563-576. [CrossRef] [PubMed]

23. Herrera, M.; Vargas-Chacoff, L.; Hachero, I.; Ruiz-Jarabo, I.; Rodiles, A.; Navas, J.I.; Mancera, J.M. Osmoregulatory changes in wedge sole (Dicologoglossa cuneata Moreau, 1881) after acclimation to different environmental salinities. Aquac. Res. 2009, 40, 762-771. [CrossRef]

24. Cardenas, S. Crianza de la Corvina (Argyrosomus regius); Fundacion Observatorio Español de Acuicultura: Madrid, Spain, 2010; Volume 3, p. 97.

25. Gonzalez-Silvera, D.; Herrera, M.; Giráldez, I.; Esteban, M.A. Effects of the dietary tryptophan and aspartate on the immune response of meagre (Argyrosomus regius) after stress. Fishes 2018, 3, 6. [CrossRef]

26. Carvalho, M.; Peres, H.; Saleh, R.; Fontanillas, R.; Rosenlund, G.; Oliva-Teles, A.; Izquierdo, M. Dietary requirement for n-3 long-chain polyunsaturated fatty acids for fast growth of meagre (Argyrosomus regius, asso 1801) fingerlings. Aquaculture 2018, 488, 105-113. [CrossRef] 
27. Magnoni, L.J.; Salas-Leiton, E.; Peixoto, M.-J.; Pereira, L.; Silva-Brito, F.; Fontinha, F.; Gonçalves, J.F.M.; Wilson, J.M.; Schrama, J.W.; Ozório, R.O.A. Dietary electrolyte balance affects growth performance, amylase activity and metabolic response in the meagre (Argyrosomus regius). Comp. Biochem. Physiol. B 2017, 211, 8-15. [CrossRef] [PubMed]

28. Millán-Cubillo, A.F.; Martos-Sitcha, J.A.; Ruiz-Jarabo, I.; Cárdenas, S.; Mancera, J.M. Low stocking density negatively affects growth, metabolism and stress pathways in juvenile specimens of meagre (Argyrosomus regius, Asso 1801). Aquaculture 2016, 451, 87-92. [CrossRef]

29. Cárdenas, C.; Toni, C.; Martos-Sitcha, J.A.; Cárdenas, S.; de la Heras, V.; Baldisserotto, B.; Heinzmann, B.M.; Vázquez, R.; Mancera, J.M. Effects of clove oil, essential oil of Lippia alba and 2-phe anaesthesia on juvenile meagre, Argyrosomus regius (Asso, 1801). J. Appl. Ichthyol. 2016, 32, 693-700. [CrossRef]

30. Poli, B.M.; Parisi, G.; Zampacavallo, G.; Iurzan, F.; Mecatti, M.; Lupi, P.; Bonelli, A. Preliminary results on quality and quality changes in reared meagre (Argyrosomus regius): Body and fillet traits and freshness changes in refrigerated commercial-size fish. Aquac. Int. 2003, 11, 301-311. [CrossRef]

31. Morales-Nin, B.; Geffen, A.J.; Perez-Mayol, S.; Palmer, M.; Gonzalez-Quiros, R.; Grau, A. Seasonal and ontogenic migrations of meagre (Argyrosomus regius) determined by otolith geochemical signatures. Fish. Res. 2012, 127-128, 154-165. [CrossRef]

32. Gonzalez-Quiros, R.; del Arbol, J.; Garcia-Pacheco, M.D.; Silva-Garcia, A.J.; Naranjo, J.M.; Morales-Nin, B. Life-history of the meagre Argyrosomus regius in the Gulf of Cadiz (SW Iberian Peninsula). Fish. Res. 2011, 109, 140-149. [CrossRef]

33. Vargas-Chacoff, L.; Ruiz-Jarabo, I.; Pascoa, I.; Goncalves, O.; Mancera, J.M. Yearly growth and metabolic changes in earthen pond-cultured meagre Argyrosomus Regius. Sci. Mar. 2014, 78, 193-202. [CrossRef]

34. Mylonas, C.C.; Pavlidis, M.; Papandroulakis, N.; Zaiss, M.M.; Tsafarakis, D.; Papadakis, I.E.; Varsamos, S. Growth performance and osmoregulation in the shi drum (Umbrina cirrosa) adapted to different environmental salinities. Aquaculture 2009, 287, 203-210. [CrossRef]

35. Jensen, M.K.; Madsen, S.S.; Kristiansen, K. Osmoregulation and salinity effects on the expression and activity of $\mathrm{Na}^{+}, \mathrm{K}^{+}$-ATPpase in the gills of European sea bass, Dicentrarchus labrax (L.). J. Exp. Zool. 1998, 282, 290-300. [CrossRef]

36. Vargas-Chacoff, L.; Saavedra, E.; Oyarzún, R.; Martínez-Montaño, E.; Pontigo, J.P.; Yáñez, A.; Ruiz-Jarabo, I.; Mancera, J.M.; Ortiz, E.; Bertrán, C. Effects on the metabolism, growth, digestive capacity and osmoregulation of juvenile of sub-Antarctic nototheniod fish Eleginops maclovinus acclimated at different environmental salinities. Fish Physiol. Biochem. 2015, 41, 1369-1381. [CrossRef]

37. Ruiz-Jarabo, I.; Klaren, P.H.M.; Louro, B.; Martos-Sitcha, J.A.; Pinto, P.I.S.; Vargas-Chacoff, L.; Flik, G.; Martínez-Rodríguez, G.; Power, D.M.; Mancera, J.M.; et al. Characterization of the peripheral thyroid system of gilthead seabream acclimated to different ambient salinities. Comp. Biochem. Physiol. A 2017, 203, 24-31. [CrossRef] [PubMed]

38. Imsland, A.K.; Gunnarsson, S.; Foss, A.; Stefansson, S.O. Gill Na ${ }^{+}, \mathrm{K}^{+}$-ATPase activity, plasma chloride and osmolality in juvenile turbot (Scophthalmus maximus) reared at different temperatures and salinities. Aquaculture 2003, 218, 671-683. [CrossRef]

39. Vargas-Chacoff, L.; Calvo, A.; Ruiz-Jarabo, I.; Villarroel, F.; Munoz, J.L.; Tinoco, A.B.; Cardenas, S.; Mancera, J.M. Growth performance, osmoregulatory and metabolic modifications in red porgy fry, Pagrus pagrus, under different environmental salinities and stocking densities. Aquac. Res. 2011, 42, 1269-1278. [CrossRef]

40. Ruiz-Jarabo, I.; Herrera, M.; Hachero-Cruzado, I.; Vargas-Chacoff, L.; Mancera, J.M.; Arjona, F.J. Environmental salinity and osmoregulatory processes in cultured flatfish. Aquac. Res. 2015, 46, 10-29. [CrossRef]

41. Ruiz-Jarabo, I.; Barany-Ruiz, A.; Jerez-Cepa, I.; Mancera, J.M.; Fuentes, J. Intestinal response to salinity challenge in the Senegalese sole (Solea senegalensis). Comp. Biochem. Physiol. A 2017, 204, 57-64. [CrossRef]

42. Lisboa, V.; Barcarolli, I.F.; Sampaio, L.A.; Bianchini, A. Effect of salinity on survival, growth and biochemical parameters in juvenile lebranch mullet Mugil liza (Perciformes: Mugilidae). Neotrop. Ichthyol. 2015, 13, 447-452. [CrossRef]

43. Armesto, P.; Infante, C.; Cousin, X.; Ponce, M.; Manchado, M. Molecular and functional characterization of seven $\mathrm{Na}^{+} / \mathrm{K}^{+}$-ATPase beta subunit paralogs in Snegalese sole (Solea senegalensis Kaup, 1858). Comp. Biochem. Physiol. B 2015, 182, 14-26. [CrossRef] 
44. Armesto, P.; Campinho, M.A.; Rodriguez-Rua, A.; Cousin, X.; Power, D.M.; Manchado, M.; Infante, C. Molecular characterization and transcriptional regulation of the $\mathrm{Na}^{+} / \mathrm{K}^{+}$ATPase alpha subunit isoforms during development and salinity challenge in a teleost fish, the Senegalese sole (Solea senegalensis). Comp. Biochem. Physiol. B 2014, 175, 23-38. [CrossRef]

45. Hsu, H.H.; Lin, L.Y.; Tseng, Y.C.; Horng, J.L.; Hwang, P.P. A new model for fish ion regulation: Identification of ionocytes in freshwater- and seawater-acclimated medaka (Oryzias latipes). Cell Tissue Res. 2014, 357, 225-243. [CrossRef]

46. Hiroi, J.; McCormick, S.D. New insights into gill ionocyte and ion transporter function in euryhaline and diadromous fish. Respir. Physiol. Neurobiol. 2012, 184, 257-268. [CrossRef]

47. McCormick, S.D. Endocrine control of osmoregulation in teleost fish. Am. Zool. 2001, 41, 781-794. [CrossRef]

48. Cadiz, L.; Roman-Padilla, J.; Gozdowska, M.; Kulczykowska, E.; Martinez-Rodriguez, G.; Mancera, J.M.; Martos-Sitcha, J.A. Cortisol modulates vasotocinergic and isotocinergic pathways in the gilthead sea bream. J. Exp. Biol. 2015, 218, 316-325. [CrossRef]

49. Ellis, T.; Yildiz, H.Y.; Lopez-Olmeda, J.; Spedicato, M.T.; Tort, L.; Overli, O.; Martins, C.I. Cortisol and finfish welfare. Fish Physiol. Biochem. 2012, 38, 163-188. [CrossRef]

50. Das, C.; Thraya, M.; Vijayan, M.M. Nongenomic cortisol signaling in fish. Gen. Comp. Endocrinol. 2018, 265, 121-127. [CrossRef]

51. Menezes, C.; Ruiz-Jarabo, I.; Martos-Sitcha, J.A.; Toni, C.; Salbego, J.; Becker, A.; Loro, V.L.; Martinez-Rodriguez, G.; Mancera, J.M.; Baldiserotto, B. The influence of stocking density and food deprivation in silver catfish (Rhamdia quelen): A metabolic and endocrine approach. Aquaculture 2015, 435, 257-264. [CrossRef]

52. Vargas-Chacoff, L.; Martinez, D.; Oyarzun, R.; Nualart, D.; Olavarria, V.; Yanez, A.; Bertran, C.; Ruiz-Jarabo, I.; Mancera, J.M. Combined effects of high stocking density and Piscirickettsia salmonis treatment on the immune system, metabolism and osmoregulatory responses of the Sub-Antarctic Notothenioid fish Eeginops Maclovinus. Fish Shellfish Immunol. 2014, 40, 424-434. [CrossRef]

53. Laiz-Carrion, R.; Viana, I.R.; Cejas, J.; Ruiz-Jarabo, I.; Jerez, S.; Martos, J.A.; Almansa, E.; Mancera, J.M. Influence of food deprivation and high stocking density on energetic metabolism and stress response in red porgy, Pagrus pagrus L. Aquac. Int. 2012, 20, 585-599. [CrossRef]

54. Herrera, M.; Ruiz-Jarabo, I.; Hachero, I.; Vargas-Chacoff, L.; Amo, A.; Mancera, J. Stocking density affects growth and metabolic parameters in the brill (Scophthalmus rhombus). Aquac. Int. 2012, 20, 1041-1052. [CrossRef]

55. Herrera, M.; Vargas-Chacoff, L.; Hachero, I.; Ruiz-Jarabo, I.; Rodiles, A.; Navas, J.I.; Mancera, J.M. Physiological responses of juvenile wedge sole Dicologoglossa cuneata (Moreau) to high stocking density. Aquac. Res. 2009, 40, 790-797. [CrossRef]

56. Soengas, J.L.; Sangiao-Alvarellos, S.; Laiz-Carrion, R.; Mancera, J.M. Energy metabolism and osmotic acclimation in teleost fish. In Fish Osmoregulation; Baldiserotto, B., Mancera, J.M., Kapoor, B.G., Eds.; Science Publishers: Enfield, NH, USA, 2008; pp. 277-307.

57. Bernatzeder, A.K.; Cowley, P.D.; Hecht, T. Do juveniles of the estuarine-dependent dusky kob, Argyrosomus japonicus, exhibit optimum growth indices at reduced salinities? Estuar. Coast. Shelf Sci. 2010, 90, 111-115. [CrossRef]

58. Mohammed-Geba, K.; Gonzalez, A.A.; Suarez, R.A.; Galal-Khallaf, A.; Martos-Sitcha, J.A.; Ibrahim, H.M.; Martinez-Rodriguez, G.; Mancera, J.M. Molecular performance of Prl and Gh/igf1 axis in the Mediterranean meager, Argyrosomus regius, acclimated to different rearing salinities. Fish Physiol. Biochem. 2017, 43, 203-216. [CrossRef] [PubMed]

59. Sangiao-Alvarellos, S.; Guzman, J.M.; Laiz-Carrion, R.; Miguel, J.M.; Martin del Rio, M.P.; Mancera, J.M.; Soengas, J.L. Actions of $17 \beta$-estradiol on carbohydrate metabolism in liver, gills, and brain of gilthead sea bream Sparus auratus during acclimation to different salinities. Mar. Biol. 2005, 146, 607-617. [CrossRef]

60. Lagardere, J.P.; Mariani, A. Spawning sounds in meagre Argyrosomus regius recorded in the Gironde estuary, Fance. J. Fish Biol. 2006, 69, 1697-1708. [CrossRef]

61. Sampaio, L.A.; Bianchini, A. Salinity effects on osmoregulation and growth of the euryhaline flounder Paralichthys Orbignyanus. J. Exp. Mar. Biol. Ecol. 2002, 269, 187-196. [CrossRef]

62. Moore, S. Amino acid analysis: Aqueous dimethyl sulfoxide as solvent for the ninhydrin reaction. J. Biol. Chem. 1968, 243, 6281-6283. 
63. Martos-Sitcha, J.A.; Wunderink, Y.S.; Straatjes, J.; Skrzynska, A.K.; Mancera, J.M.; Martinez-Rodriguez, G. Different stressors induce differential responses of the CRH-stress system in the gilthead sea bream (Sparus aurata). Comp. Biochem. Physiol. A 2014, 177, 49-61. [CrossRef]

64. McCormick, S.D. Methods for nonlethal gill biopsy and measurement of $\mathrm{Na}^{+}, \mathrm{K}^{+}$-ATPase activity. Can. J. Fish. Aquat. Sci. 1993, 50, 656-658. [CrossRef]

65. Mancera, J.M.; Laiz Carrion, R.; Martín del Río, M.P. Osmoregulatory action of PRL, GH, and cortisol in the gilthead seabream (Sparus aurata 1.). Gen. Comp. Endocrinol. 2002, 129, 95-103. [CrossRef]

66. Vargas-Chacoff, L.; Ruiz-Jarabo, I.; Arjona, F.J.; Laiz-Carrion, R.; Flik, G.; Klaren, P.H.M.; Mancera, J.M. Energy metabolism of hyperthyroid gilthead sea bream Sparus aurata L. Comp. Biochem. Physiol. A 2016, 191, 25-34. [CrossRef] [PubMed]

67. Keppler, D.; Decker, K. Glycogen determination with amyloglucosidase. In Methods of Enzymatic Analysis; Bergmeyer, H.U., Ed.; Academic Press: New York, NY, USA, 1974; Volume 3, pp. 1127-1131.

(C) 2018 by the authors. Licensee MDPI, Basel, Switzerland. This article is an open access article distributed under the terms and conditions of the Creative Commons Attribution (CC BY) license (http://creativecommons.org/licenses/by/4.0/). 